\title{
TATAKELOLA SYARIAH \\ PADA BANK SYARIAH
}

Oleh :

\section{Ahmad Faqihuddin}

Faqihuddin25@gmail.com

FAKULTAS AGAMA ISLAM

UNIVERSITAS ISLAM ASSYAFIIYAH

JAKARTA 


\begin{abstract}
Abstrak
Penerapan sistem good corporate governance dalam perbankan syariah diharapkan dapat meningkatkan kepercayaan dan meningkatkan nilai tambah bagi semua pihak yang berkepentingan. Sistem pengukuran kinerja melalui tata kelola syariah yang baik, bank syariah dapat memperoleh keuntungan dari sistem ini dan dapat meningkatkan nilai tambah bagi semua pihak yang berkepentingan. Kegiatan usaha perbankan syariah yang benar-benar menggunakan prinsip syariah harus menekankan aspek tanggung jawab untuk meyakinkan nasabah bahwa produk dan kegiatan operasional dilaksanakan secara transparan dan dapat dipertanggungjawabkan sesuai dengan prinsip-prinsip syariah dimana setiap transaksi ekonominya tidak terdapat unsur-unsur yang diharamkan seperti riba, mysir, gharar, objek haram yang menimbulkan kedzaliman. Bank syariah pada umumnya belum mampu menerapkan nilai-nilai dan hukum islam (maqashid syariah) karena kelemahan sistem pengukuran kinerja. Pengukuran dapat dilakukan dengan menggunakan pengukuran keuangan dan pengukuran non keuangan. Pengukuran keuangan biasanya untuk perusahaan bank konvensional. Bank syariah dan unit syariah biasanya menggunakan pengukuran non keuangan. Pengukuran berdasarkan nilai-nilai Islam menunjukkan tingkat yang lebih tinggi dibandingkan dengan pengukuran yang dilakukan oleh bank konvensional yang bertujuan semata-mata memaksimalkan nilai pemegang saham.
\end{abstract}

Keyword : Tata kelola, Pengukuran, Tanggung Jawab, Riba

\title{
A. Muqoddimah
}

Industri perbankan nasional merupakan bagian dari penopang sektor rill nasional, yang memiliki kewajiban untuk menerapkan good corporate governance (GCG). Pada saat ini penerapan tata kelola perusahaan yang baik (good corporate governance) merupakan suatu kebutuhan sebagai barometer akuntabilitas dari suatu perusahaan. Masih lemahnya penerapan corporate governance diduga sebagai salah satu pemicu terjadi berbagai skandal keuangan pada bisnis perusahaan. Penerapan good corporate governance dinilai dapat memperbaiki citra perusahaan yang buruk, melindungi stakeholders serta meningkatkan kepatuhan terhadap peraturan perundangundangan yang berlaku dan etika-etika umum pada dunia bisnis. Perusahaan 
dengan praktik good corporate governance (GCG) yang baik akan dapat meningkatkan nilai perusahaan bagi pemegang skarena visi, misi dan strategi perusahaan dinyatakan dengan jelas, nilai-nilai perusahaan serta kode etik disusun untuk memastikan adanya kepatuhan seluruh jajaran perusahaan, yang terdapat kebijakan untuk menghindari adanya benturan kepentingan dan transaksi dengan pihak ketiga yang tidak tepat, serta risiko perusahaan dikelola dengan baik dan terdapat sistem pengendalian dan monitoring yang baik. $^{1}$

${ }^{1}$ Dewi Fitriyani., dkk. "Good corporate governance Dan dampaknya Terhadap kinerja berdasarkan Balanced scorecard”. Jurnal Akuntansi/Volume XX, No. 03, September 2016: 420-447 
Menurut Komite Nasional Kebijakan Corporate Governance (KNKCG), corporate governance adalah suatu proses dan struktur yang digunakan oleh organ perusahaan guna memberikan nilai tambah pada perusahaan secara berkesinambungan dalam jangka panjang bagi pemegang saham dengan tetap memperhatikan kepentingan stakeholder lainnya berlandaskan peraturan perundangan dan norma yang berlaku.

\section{B. Pilar Penting Good Corporate Governance (GCG)}

Sistem keuangan Islam merupakan bagian dari konsep yang luas mengenai ekonomi Islam yang mana tujuannya adalah memberlakukan sistem nilai dan etika Islam dalam lingkungan ekonomi. Perkembangan perbankan syariah semakin meningkat dan cepat, tetapi satu hal perlu dicermati adalah aspek Good Coorporate Govarnance (GCG) karena terkait dengan berbagai macam resiko kerugian apabila tidak diperhatikan maka akan merusak citra syariah bank syariah.

Good Corporate Governance merupakan pilar penting diciptakan untuk mewujudkan bank syariah yang unggul. Penerapan Good Corporate Governance (GCG) semakin penting, karena konsep bank syariah menggunakan risk sharing. Pelaksanaan good corporate governance pada industri perbankan syariah harus berlandaskan pada lima prinsip dasar. Pertama, transparansi (transparency), yaitu keterbukaan dalam mengemukakan informasi yang material dan relevan serta keterbukaan dalam proses pengambilan keputusan. Kedua, Akuntabilitas (accountability), yaitu kejelasan fungsi dan pelaksanaan pertanggungjawaban organ bank sehingga pengelolanya berjalan secara efektif. Ketiga, pertanggungjawaban (responsibility), yaitu kesesuaian pengelola bank dan peraturan perundang-undangan yang berlaku dan prinsip-prinsip pengelolaan bank yang sehat. Keempat, profesional (professional), yaitu memiliki kompetensi, mampu bertindak obyektif dan bebas dari pengaruh/tekanan dari pihak manapun (independent) serta 
memiliki komitmen yang tinggi untuk mengembangkan bank syariah. Kelima, kewajaran (fairness), yaitu keadilan dan kesetaraan dalam memenuhi hak-hak stakeholders berdasarkan perjanjian peraturan perundang-undangan yang berlaku. ${ }^{2}$

Penerapan sistem Good corporate governance dalam perbankan syariah diharapkan dapat meningkatkan nilai tambah bagi semua pihak yang berkepentingan (stakeholders) melalui beberapa tujuan berikut: 1) Meningkatkan efisiensi, efektifitas, dan kesinambungan suatu organisasi yang memberikan kontribusi kepada terciptanya kesejahteraan pemegang saham, pegawai dan stakeholders lainnya dan merupakan solusi yang elegan dalam menghadapi tantangan organisasi kedepan; 2) Meningkatkan legitimasi organisasi yang dikelola dengan terbuka, adil, dan dapat dipertanggungjawabkan; 3) Mengakui dan melindungi hak dan kewajiban para stakeholders; 4) Pendekatan yang terpadu berdasarkan kaidah-kaidah demokrasi, pengelolaan dan partisipasi organisasi secara legitimasi; 5) Mengendalikan konflik kepentingan yang mungkin timbul antar pihak prinsipal dengan agen; 6) Meminimalkan biaya modal dengan memberikan sinyal positif untuk para penyedia modal. Meningkatkan nilai perusahaan yang dihasilkan dari biaya modal yang lebih rendah, meingkatkan kinerja keuangan dan persepsi yang lebih baik dari para stakeholders atas kinerja perusahaan di masa depan. ${ }^{3}$

Bank syariah saat ini juga belum diikuti oleh market share, sehingga diperlukan suatu strategi untuk meningkatkan market share bank syariah dengan mengimplementaskan shariah governance yang merupakan perpaduan antara good corporate governance (GCG) yang universal dengan

\footnotetext{
${ }^{2}$ Muhammad Ghafur W, Potret Perbankan Syariah Indonesia Terkini (Kajian Kritis Perkembangan Perbankan Syariah) (Yogyakarta : Biruni Press, 2007), 135.

3 Aldira Maradit. "Karakteristik Good Corporate Governance Pada Bank Syariah Dan Bank Konvensional.” Yuridika : Volume 29 No 2, Mei-Agustus 2014.
} 
implementasi terhadap prinsip-prinsip syariah (shariah compliance) agar dapat meningkatkan reputasi dan kepercayaan nasabah bank syariah. ${ }^{4}$ Kepatuhan dan kesesuaian bank terhadap prinsip syariah sering dipertanyakan oleh para nasabah. Secara implisit menunjukkan bahwa praktik perbankan syariah kurang memperhatikan prinsip-prinsip syariah, salah satu penyebab rendahnya adalah reputasi bank syariah. Reputasi memegang peran yang penting dalam menjalin hubungan kerjasama antar bank syariah dengan nasabah, dalam jangka panjang.. ${ }^{5}$

Bank Islam juga belum mampu menerapkan nilai-nilai dan hukum Islam (maqashid shariah) karena kelemahan sistem pengukuran kinerja ${ }^{6}$. Pengukuran dapat dilakukan dengan menggunakan pengukuran keuangan dan pengukuran non keuangan. Pengukuran keuangan biasanya untuk perusahaan bank konvensional. Bank syariah dan Usaha Unit Syariah biasanya menggunakan pengukuran non keuangan. Pengukuran berdasarkan nilai-nilai Islam menunjukan tingkat yang lebih tinggi dibandingkan dengan pengukuran yang dilakukan bank konvensional yang bertujuan semata-mata memaksimalkan nilai pemegang saham ${ }^{7}$ Mehmet Asutay dan Astrid Fionna Harningtyas dalam penelitiannya menjelaskan adanya bukti empiris tidak sepenuhnya kegiatan operasional industri keuangan dan perbankan Islam

\footnotetext{
${ }^{4}$ Rahman El Junusi. "Implementasi Syariah Governance Serta Implikasinya Terhadap Reputasi Dan Kepercayaan Bank Syariah.” Al-Tahrir, Vol. 12, No. 1 Mei 2012 : 91-115.

${ }^{5}$ Siti Maria Wardayati. "Implikasi Shariah Governance Terhadap Reputasi Dan Kepercayaan Bank Syariah.” Walisongo, Volume 19, Nomor 1, Mei (2011).

${ }^{6}$ Ali, Muhammad Ahmar Bin. 2014. "Determinants of Maqasid Al-Shariah-Based Performance Measurement Practices : The Case of Malaysian Islamic Banks"."(Disertasi). Kulliyyah of Economics and Management Sciences International Islamic University Malaysia

${ }^{7}$ Obaidullah, M., "Rating of Islamic Financial Institutions-Some Methodological Suggestions", (Saudi Arabia : Scientific Publishing Centre, King Abdulaziz University), 2005.
} 
menggunakan hukum dan nilai nilai Islam $^{8}$ Hasil pengukuran kinerja sangat penting bagi semua pihak yang mempunyai kepentingan karena implementasi yang benar dari Good Syariah Governance merupakan suatu cara yang diyakini oleh penelitian terdahulu untuk menjamin manjemen bertindak atas kepentingan stakeholders. Sebagai informasi perusahaan yang merupakan wujud transparansi dan akuntabilitas manajemen perusahaan kepada stakeholders.

Keterbukaan informasi dari perusahaan dapat digunakan sebagai bahan pertimbangan bagi stakeholders dalam pengambilan keputusan, ${ }^{9}$ Penelaah lebih mendalam menghasilkan kaitan antara penerapan Good Syariah Governance dengan informasi yang diungkapkan oleh manajemen ${ }^{10}$. Sistem pengukuran kinerja melalui tatakelola syariah yang baik bukan hanya untuk Bank Syariah termasuk juga bank konvensional. Bank Syariah dapat memperoleh keuntungan dari sistem ini baik untuk tingkat Bank Umum Syariah maupun Unit Usaha Syariah. Pihak-pihak lain yang mempunyai kepentingan seperti depositor akan memperoleh keuntungan dalam keputusan mereka dalam menempatkan dana-dananya dan debitur dapat memperoleh keuntungan dalam mencari pendanaan usahanya sedangkan pemerintah akan mendapat benefitnya untuk tujuan pembuatan peraturan. Sistem penilaian kinerja melalui tatakelola yang baik Bank Syariah akan dikaitkan dengan tujuan strategis Bank Syariah yakni

${ }^{8}$ Asutay, Mehme I and Harninternational, Astrid Fionna, "Developing Maqasid AlShariah Index to Evaluate Social Performance of Islamic Banks : A Conceptual and Empirical Attempt" Journal of Islamic Economics and Finance Studies, Year 1 Volume 1, Number 1 (2015).

9 Almilia, L. S. dan Retrinasari, I. 2007. Analisis Pengaruh Karakteristik Perusahaan terhadap Kelengkapan Pengungkapan dalam Laporan Tahunan Perusahaan Manufaktur yang Terdaftar di BEJ. Proceeding Seminar Nasional Inovasi dalam Menghadapi Perubahan Lingkungan Bisnis. Jakarta.

${ }^{10}$ Khomsiyah. 2003. "Hubungan Corporate Governance dan Pengungkapan Informasi : Pengujian secara Simultan". Jurnal Simposium Nasional Akuntansi VI, Oktober : 200-213 
untuk mencari sistem yang lebih relevan dengan nilai-nilai Islam.

Indonesia adalah Negara dengan penduduk muslim terbesar di dunia namun perkembangan bisnis syariah tidak sebesar dibanding dengan Negara muslim yang lebih kecil dari Indonesia. Pertumbuhan Bank Umum Syariah (BUS) dan Unit Usaha Syariah (UUS) sejak di sahkannya Undang-Undang Perbankan Syariah No.21 Tahun 2008, pertumbuhan assetnya pada tahun 2011 - 2014 masing masing 50\%, 30\%, 4\% dan 3\% ${ }^{11}$. Pertumbuhan perbankan Syariah di Negara lain yang penduduk Muslimnya lebih kecil dari Indonesia, pertumbuhannya sebagai berikut, Malaysia tahun 2011-2014 masing masing 28\%, 27\%, 8\%, 4\% dan 1\%; Pakistan tahun 2011 - 2014 masing masing 29\%, 25\% 27\% dan 19\% ${ }^{12}$. Sedangkan market share Bank Syariah pada tahun $2010-0,5 \%, 2011-0,6 \%, 2012-0,3 \%, 2013-0,3 \%$ dan $2014-0,1 \%$ dari total perbankan nasional ${ }^{13}$. Sementara perkembangan market share Bank Syariah di Negara dengan penduduk muslim dibawah Indonesia sebagai berikut $^{14}$ : Malaysia tahun 2010 -2014 masing masing 1\%, $1,6 \%, 1,2 \%, 1,2 \%$ dan 0,6\%; Pakistan tahun 2010-2014 masing 0,7\%, 1,1\%, $0,6 \%, 1 \%$ dan $0,9 \%$

Kegiatan usaha Perbankan Syariah yang menggunakan prinsip syariah yaitu adanya aspek tanggung jawab untuk meyakinkan stakeholders bahwa produk dan kegiatan operasional dilaksanakan secara transparan dan dapat dipertanggung jawabkan sesuai prinsip prinsip syariah dimana setiap transaksi ekonominya tidak terdapat unsur unsur yang diharamkan seperti riba (bunga bank), maysir (judi), gharar (ketidak pastian), objek haram dan

\footnotetext{
${ }^{11}$ Ernst \& Young, 2016, "World Islamic Banking Competitiveness Report 2016". http://www.ey.com/Publication/, 13

${ }^{12}$ Ernst \& Young , 2016, "World Islamic Banking Competitiveness Report 2016". http://www.ey.com/Publication/,13.

${ }^{13}$ Ernst \& Young, 2016, "World Islamic Banking Competitiveness Report 2016". http://www.ey.com/Publication/,14.

${ }^{14}$ Ernst \& Young, 2016, "World Islamic Banking Competitiveness Report 2016". http://www.ey.com/Publication/,14.
} 
menimbulkan kezaliman. Seiring dengan perkembangan Perbankan Syariah di Indonesia, yang belum sepesat Negara muslim lainnya, telah terjadi kasus penyimpangan kegiatan operasional yang tidak syariah yaitu transaksi derivative (gharar) pada Unit Usaha Syariah Bank Danamon Tbk ${ }^{15}$. Transaksi derivative mengandung unsur spekulatif di perbankan syariah merupakan produk yang diharamkan dalam prinsip syariah. Kredit fiktif yang terjadi di Unit Usaha Syariah Bank Kaltim dan Bank Jateng yang dilakukan oleh Kepala Cabang dan staffnya di dua Unit Usaha Syariah tersebut. ${ }^{16}$ Kejadian penyimpangan lain bisa saja terjadi di lapangan karena luput pengawasan dari otoritas perbankan yaitu Otoritas Jasa Keuangan (OJK) yang tidak tercatat transaksi-transaksinya di perbankan atau diluar kendali OJK seperti proses akad, jenis investasi dan penyaluran pembiayaannya.

Hal yang penting bagi perkembangan perbankan syariah atau lembaga keuangan adalah pelaksanaan Good Corporate Governance dalam tubuh institusi syariah. Dengan mengusung nama perbankan syariah, atau lembaga keuangan syariah, apakah secara otomatis menjamin telah dapat mengimplimentasikan Good Corporate Governance dalam lembaganya. Studi penelitian tentang pelaksanaan Corporate Governance yang dilakukan oleh IRTI di perbankan syariah diberbagai negara menunjukkan pelaksanaan Good Corporate Governance belum terlaksana dengan baik. Penerapan Good Corporate Governance terbukti di beberapa lembaga keuangan syariah di dunia Muslim dapat meningkatkan kepercayaan

\footnotetext{
${ }^{15}$ Bank Indonesia "Bank Indonesia Tegur Unit Usaha Syariah Danamon Terkait Derivatif" diunduh 2 Januari 2018

${ }^{16}$ Nurhayati, Ida dan Metekohy, EY. 2017. "Pelanggaran Prinsip Good Corporate Governance Dalam Perbankan Sebagai Bagian White Collar Crime”. /jurnal.pnj.ac.id/, 2
} 
masyarakat kepada bank syariah tetapi apabila kegagalan dalam penerapan prinsip syariah akan membuat nasabah pindah ke bank lain. ${ }^{17}$

Shariah governance muncul ditengah tengah kebangkitan ekonomi Islam, Ekonomi Islam bangkit ketika terjadi krisis ekonomi pada awal 1997 dimana bank-bank dan lembaga keuangan konvensional hampir semuanya collapse dan di likuidasi, kecuali Bank Syariah dan Unit Usaha Syariah. Bank Syariah dan Unit Usaha Syariah bertumbuh pesat dan sejak tahun 1998, ekonomi Islam ditandai dengan sistem perbankan Islam. Sistem perbankan Islam berdasarkan syariah yaitu sistem yang mendasarkan pada Al Qur'an dan Hadits. Al Qur'an surat Al-Baqoroh ayat 22 bahwa Allah SWT mengamanatkan hendaklah jujur dalam berbisnis, dan beberapa surat surat lainnya dalam Al Qur'an yang berbicara tentang berbisnis syariah yaitu QS. Al-Baqarah : 275, QS. At-Taubah : 24, QS. An-Nur : 37, QS. Fathir : 29, QS. Ash-Shaff : 10 dan QS. Al-Jumu'ah : 11 dan sabda Rosululloh Nabi Muhammad SAW, diantaranya beliau bersabda : "Tidak dibenarkan seorang muslim menjual satu jualan yang mempunyai aib, kecuali ia menjelaskan aibnya" (H.R. Al-Quzwani). "Siapa yang menipu kami, maka dia bukan kelompok kami” (H.R. Muslim).

Shariah governance merupakan konsep tata kelola yang unik dan khusus bagi perusahaan atau lembaga keuangan yang menawarkan produk dan jasa yang sesuai dengan prinsip syariah. Shariah governance hakekatnya menjadi komplementer dari sistem tata kelola perusahaan yang baik (good corporate governance) yang sudah ada yang fungsi utamanya untuk melakukan review atas kepatuhan syariah atas seluruh aktivitas perusahaan baik sebelum terjadinya transaksi (ex-ante) maupun setelah terjadinya transaksi (ex-post).

17 Chapra, M.U. and Ahmed, H., "Corporate Governance in Islamic Financial Institutions," Occasional Paper No. 6, (Jeddah: Islamic Research \& Training Institute/Islamic Development Bank, 2002), pp. 58-67 
Untuk menjalankan fungsi tersebut, sistem shariah governance harus memiliki tiga komponen utama, yaitu dewan syariah (DPS), opini kepatuhan syariah dan proses review syariah ${ }^{18}$. Sistem transaksi bisnis syariah terdiri dari mudharabah (bagi hasil), qardh (pinjaman), musyarakah (kongsi), akad salam (pesan barang), rahn (gadai), kafalah ( tanggung jaminan), dan wadiah (titipan). Sedangkan prinsip syariah yaitu adanya aspek tanggung jawab untuk meyakinkan stakeholders bahwa produk dan kegiatan operasional dilaksanakan secara transparan dan dapat dipertanggung jawabkan sesuai prinsip-prinsip syariah yangmana setiap transaksi ekonominya tidak terdapat unsur unsur yang diharamkan seperti riba (bunga bank), maysir (judi), gharar (ketidak pastian), objek haram dan menimbulkan kezaliman.

Penelitian Chapra \& Ahmad menjelaskan, dimana sejumlah 288 nasabah (62\%) responden dari 463 nasabah yang terlibat dalam survei tata kelola (GCG) yang dilakukannya (berasal dari 14 bank syariah di Bahrain, Bangladesh dan Sudan) menjawab akan memindahkan dananya ke bank syariah yang lain jika ditengarai apabila terjadi "pelanggaran syariah" dalam operasional bank syariah. ${ }^{19}$ Hal ini menunjukan bahwa aspek kepatuhan terhadap prinsip syariah amat signifikan mempengaruhi perilaku nasabah dalam memilih bank syariah. Oleh karena itu, penerapan shariah governance bank syariah merupakan keharusan dan hal ini diharapkan dapat meningkatkan reputasi dan kepercayaan masyarakat terhadap bank syariah.

Hingga saat ini definisi Corporate Governance tidak dapat diklaim oleh orang-perorang karena setiap orang berbeda-beda dalam mendefinisikannya. Diantara yang mendefinisi Good Corporate Governance berbeda satu

\footnotetext{
${ }^{18}$ Rama, Ali “Analisisi Kerangka Regulasi Model Shariah Governance Lembaga Keuangan Syariah Di Indonesia http://journal.uii.ac.id/index.php/JIELariba/article/view/3711/3451 diunduh 16 Januari 2018.

${ }^{19}$ M. Umer Chapra and Habib Ahmed. "Corporate Governance in Islamic Financial Institutions." Occasional Paper No. 6 (Islamic Research and Training Institute/ Islamic Development Bank, Jeddah (2002), 12-13
} 
dengan lainnya OECD, ADB dan Cadbury Committee. Pada dasarnya Good Corporate Governance memiliki paling tidak ada 3 (tiga) unsur. Pertama, adanya Dewan Komisaris, Direksi, Pemegang Saham dan stakeholder; kedua, adanya internal control dan ketiga, adanya transparansi dalam penentuan tujuan perusahaan, dan pengukuran kinerja perusahaan. Prinsipprinsip Good Corporate Governance adalah Transparansi (Transparency), Kemandirian (Independency), Akuntabilitas (Accountability), Pertanggungjawaban (Responsibility), dan Kewajaran (Fairness). ${ }^{20}$

Pengukuran berdasarkan nilai-nilai Islam menunjukan tingkat yang lebih tinggi dibandingkan dengan pengukuran yang dilakukan bank-bank konvensional yang bertujuan semata-mata memaksimalkan nilai pemegang saham. ${ }^{21}$ Ada beberapa metode pengukuran kinerja bank syariah diantara adalah index maqashid syariah dan balance scorecard shariah. Maqashid syariah yang diadaptasi dari rumusan maqasid syariah oleh Abu Zahrah mengklasifikasikan konsep maqasid syariah menjadi: 1) Mendidik individu, 2) Menegakkan keadilan, dan 3) Memelihara kemaslahatan ${ }^{22}$.

Good governance di perbankan syariah jauh lebih penting dibanding di perbankan konvensional karena depositor/investor menghadapi risiko yang lebih tinggi pada kontrak bagi hasil ${ }^{23}$. Pengesahan Undang Undang No.21 Tahun 2008 tentang Perbankan Syariah menunjukan seriusnya pengaturan aktifitas operasional perbankan syariah antara lain di pasal 34 dengan kewajiban Bank Syariah untuk melaksanakan Good Governance,

${ }^{20}$ Arifin, Peran Akuntan Dalam Menegakkan Prinsip Good Corporate Governance Pada Perusahaan Di Indonesia (Tinjauan Perspektif Teori Keagenan), disampaikan pada sidang senat guru besar Universitas Diponegoro dalam rangka pengusulan jabatan guru besar, FEUndip, Semarang, 2005.

${ }^{21}$ Obaidullah, M., "Rating of Islamic Financial Institutions - Some Methodological Suggestions", (Jeddah : Scientific Publishing Centre, King Abdulaziz University, 2005),

${ }^{22}$ Zahrah, Muhammad Abu, Ushul al-Fiqh (Kairo: Dar al-Fikr alArabi, 1997),

${ }^{23}$ Satkunasingam, E dan Shanmugam, B. "Disclosure and Governance of Islamic Banks- A Case Study of Malaysia". Journal of International Banking Regulation, 6 (1) (2004.): $69-81$. 
kemudian dikeluarkannya Peraturan Bank Indonesia No.11/33/PBI/2009 tanggal 7 Desember 2009 dan Surat Edaran Bank Indonesia No.12/13/DPbS tanggal 30 April 2010 tentang Pelaksanaan Good Corporate Governance bagi Bank Umum Syariah dan Unit Usaha Syariah. Kedua peraturan mengatur kepatuhan bank syariah terhadap syariah. Good Governance Bank Syariah dan Pelaksanaan Good Corporate Governance Bank Umum Syariah (BUS) dan Unit Usaha Syariah (UUS) untuk meningkatkan kepercayaan public dengan mengaplikasikan prinsip transparansi, akuntabilitas, pertanggung jawaban, professional dan kewajaran dalam menjalankan kegiatan operasional bank syariah.

Penerapan Good Corporate Governance (GCG) pada bank syariah harus merujuk pada prinsip dan nilai-nilai ekonomi dan bisnis Islam sesuai dengan Al Qur'an dan Hadis. Penyimpangan kegiatan operasional bank syariah terhadap nilai-nilai ekonomi dan bisnis Islam berarti penyimpangan terhadap akidah Islam. Al Qurán dan Hadits tidak hanya mengatur nilai-nilai ekonomi dan bisnis tetapi juga mengatur akhlak manusia yang ideal sebagai pelaku kegiatan ekonomi dan bisnis dalam perbankan syariah.

\section{Kesimpulan}

Indonesia merupakan negara dengan penduduk muslim terbesar di dunia namun perkembangan bisnis syariah tidak sebesar dibanding dengan negara muslim yang lebih kecil dari Indonesia. Kegiatan usaha perbankan syariah yang menggunakan prinsip syariah harus menekankan aspek tanggung jawab sesuai dengan prinsip-prinsip syariah dimana setiap transaksi bank syairah tidak terdapat unsur yang diharamkan. Penerapan sistem good coorporate goverment dalam perbankan syariah diharapkan dapat meningkatkan nilai tambah bagi semua pihak yang berkepentingan atau stakeholder. 


\section{Daftar Pustaka}

Alamsyah, Halim. 2012. "Perkembangan Dan Prospek Perbankan Syariah Indonesia Tantangan Dalam Menyongsong MEA 2015". Ceramah Ilmiah Ikatan Ahli Ekonomi Islam (IAEI), Milad ke-8 IAEI, Accessed July 7, 2012.http://www.bi.go.id/.

Ali, Muhammad Ahmar Bin. 2014. "Determinants Of Maqasid Al-Shariah Based Measurement Practices : The Case of Malaysian Islamic Banks" (Disertasi). International Islamic University Malaysia.

Bank Indonesia “Bank Indonesia Tegur Unit Usaha Syariah Danamon Terkait Derivatif” diunduh 2 Januari 2018

Bank Indonesia. 2009.” Pelaksanaan Good Corporate Governance Bagi Bank Umum Syariah dan Unit Usaha Syariah" PBI Nomor 11/33/PBI/2009 tanggal 7 Desember 2009 -

Dusuki, Asyraf Wajdi dan Abdullah, Nurdianawati Irwani. (n.d). "Maqasid al Shari`ah, Maslahah, and Social Responsibility". The American Journal of Islamic Social Sciences, 24:1

Ernst \& Young , 2016, "World Islamic Banking Competitiveness Report 2016". http://www.ey.com/Publication/

Fitriyani, Dewi, dkk. "Good corporate governance Dan dampaknya Terhadap kinerja berdasarkan Balanced scorecard". Jurnal Akuntansi/Volume XX, No. 03, September 2016: 420-447

Ismail, A.Ilyas dkk, (2016). Panduan Penulisan Skripsi, Universitas Islam Assyafiiyah, Jakarta.

Junusi, Rahman El "Implementasi Syariah Governance Serta Implikasinya Terhadap Reputasi Dan Kepercayaan Bank Syariah.” Al-Tahrir, Vol. 12, No. 1 Mei 2012 : 91-115

Maradit, Aldira. 2014. "Karakteristik Good Corporate Governance Pada Bank Syariah Dan Bank Konvensional.” Yuridika : Volume 29 No 2, Mei-Agustus.

Mervyn K. Lewis dan Latifa M. Algaud, (2007). Perbankan Syariah, terj. 
Burhan Subrata . Jakarta: Serambi Ilmu Semesta.

Nienhaus, V., 1983, "Profitability of Islamic PLS Banks Competing with Interest Banks: Problems and Prospects", Journal of Research in Islamic Economics Vol. 1 No. 1.

Rama, Ali "Analisisi Kerangka Regulasi Model Shariah Governance Lembaga Keuangan Syariah Di Indonesia" http://journal.uii.ac.id/index.php/JIELariba/article/view/3711/3451 diunduh 16 Januari 2018

Samad, A. and Hassan, M. K., 2002, "The Performance of Malaysian Islamic Bank During 1984-1997: an Exploratory Study", International Journal of Islamic Financial Services Vol. 1 No. 3.

Sarker, M. A. A., 1999, "Islamic Banking in Bangladesh: Performance, Problems and Prospects", International Journal of Islamic Financial Services Vol. 1 No. 3.

W, Muhammad Ghafur W. 2007. Potret Perbankan Syariah Indonesia Terkini (Kajian Kritis Perkembangan Perbankan Syariah) (Yogyakarta : Biruni Press).

Wardayati, Siti Maria. (2011)."Implikasi Shariah Governance Terhadap Reputasi Dan Kepercayaan Bank Syariah.” Walisongo, Volume 19, Nomor 1, Mei

Zahrah, Muhammad Abu. Ushul al-Fiqh, Kairo: Dar al-Fikr alArabi, 1997

Zed, Mestika. (2004). Metode Penelitian. Kepustakaan. Yayasan Obor Indonesia: Jakarta. 